日臨外会誌 $67(4), 899-903 ， 2006$

症 例

虫垂炎術後に菌塊を核として発症した大網肉芽腫（Braun 腫瘤）の 1 例

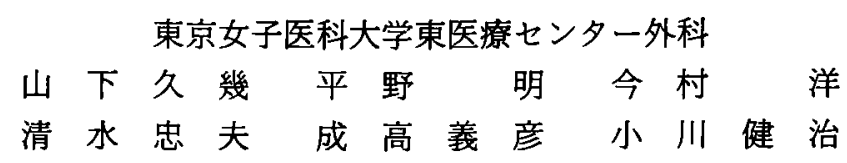

虫垂炎術後に菌塊を核として発症した大網肉芽腫（Braun 腫瘤）を経験したので報告 する. 症例は10歳, 男性. 虫垂切除後とその術後合併症としての腹壁澧瘍の既往がある. 虫垂切除術の 3 年後に右下腹部痛, 発熱で当科を受診した. 右下腹部に著明な発赤と圧 痛がみられた．腹部超音波検査で皮下から腹腔内に連続する低エコー領域を認め, 腹部 $\mathrm{CT}$ 検查では腹壁筋の炎症像とそれに連続する造影効果を伴う腹腔内腫瘤を認めた。腹 壁から連続する腹腔内腫痹あるいは膿瘍の診断で開腹術を施行した．腹壁筇には著しい 炎症性肥厚と硬化がみられ, 腹肤内にはそれと強固に痹着し, 大網が集束したような形 態の腫瘤性病変を認めた。腫瘤は菌塊を核とした大網肉芽腫（Braun 腫瘤）であった。

索引用語：虫垂切除術, 大網肉芽腫 (Braun 腫瘤), Schloffer 腫瘤

\section{はじめに}

大網肉芽腫（Braun 腫瘤）とは，結禁系などを中心 として発生する大網の炎症性肉芽腫と定義される゙1. 今回, 虫垂炎術後に菌塊を核として発症した本症を経 験した，成因として稀と考え報告する。

$$
\text { 症例 }
$$

患者: 10歳, 男性.

主訴: 右下腹部痛, 発熱.

既往歴：4 年前に虫垂切除術とその術後合併症とし ての腹壁膿瘍（術後 2 週間目）.

現病歴: 右下腹部痛, 発熱が出現し当科を受診, 皮 下朖瘍の診断で入院した。

入院時現症：身長 $150 \mathrm{~cm}$ ，体重 $37 \mathrm{~kg}$ ．血圧 $120 / 70$ $\mathrm{mmHg}$, 脈拍 $84 / \mathrm{min}$, 体温 $37.1^{\circ} \mathrm{C}$. 右下腹部に虫垂切 除術の手術痕がみられ, 同部位を中心に発赤と腫脹が あり，著明な圧痛と反跳痛を認めた。

血液生化学所見：白血球数 $10,700 / \mathrm{m}^{3}, \mathrm{CRP} 1.85$ $\mathrm{mg} / \mathrm{dl}$ と軽度の炎症所見を認めた。

腹部単純 $\mathbf{X}$ 線検查：大腸ガスの軽度増加がみられ たが，小腸の異常ガス像や鏡面像は認めなかった。

腹部エコー検査 : 虫垂切除術後の瘦痕部の皮下組織

2006年 1 月18日受付 2006年 2 月 9 日採用 〈所属施設住所〉

下116-8567 東京都荒川区西尾久 $2-1-10$
内から腹壁筋群を貫き, 腹腔内まで連続する不整形で 境界不明瞭な低エコー領域を認めた（図 1 ).

腹部造影 CT 検査：右腹壁筋群の著明な腫脹と表面 平滑で辺縁に造影効果を伴う腹腔内腫瘤を認めた(図 2).

マルチスライス画像 : 矢状断面像で, 肥厚した腹壁 筋群とそれに連続する腹腔内腫瘤がみられた，冠状断 面像で, 腹壁筋群の著明な肥厚と腫瘤, それによる上 行結腸の圧排所見がみられた（図 3 ).

以上より，腹壁筋内の膿瘍とそれに連続する腹腔内 腫瘤あるいは腫瘍の診断で開腹術を施行した。

手術所見：腹壁筋群の一部に著しい炎症性肥厚と硬 化を認めた。筋内に明らかな膿暘はなかった。筋組織 を一部切除して腹腔内に至ると, 腹壁笳群に瘾着し, 大網が収束したような形態の腫瘤性病変を認めた（図 4).肥厚した腹壁筋群の一部, 周囲の大網とともに腫 瘤を切除した。腹壁欠損部を縫合閉鎖し，皮下に吸引 ドレーンを留置して閉腹した。

切除標本：腹壁笳群の一部が肥厚して硬化し, 腫瘤 を形成していた，さらに大網と連続し，それが集束し たような形態の表面平滑な腫瘤がその腹壁筋群と強固 に瘾着していた（図 5).

病理組織学的所見 : 腹壁筋群には炎症性細胞浸潤と 殄原線維の増生がみられた。腹腔内の腫瘤は, 膿瘍を 伴う大網の炎症性肉芽腫であった。肉芽腫部分には炎 症性細胞浸潤，リンパ滤胞の増生があり，その中心に 
菌塊を認めた（図6).

術後経過：術後経過は良好で, 術後第 4 病日に退院 した。

\section{考 察}

Braun腫瘤とは大網に生じた炎症性腫瘤で, Braun ${ }^{13}$ がヘルニア手術後の炎症性大網腫㿇症例を集 計し報告したことでその呼称がある.成因と関連して， 狭義には結紮系とくに組系" とされるが，田中ら2)の本邦における炎症性大網腫瘤 58例の集計では，結禁禾に起因するものは 8 例と少な い. 他方，その他の遺残した異物を核とするものを広 義の Braun 腫瘤とする場合があり ${ }^{3)}$ ，成因には遺残ガ

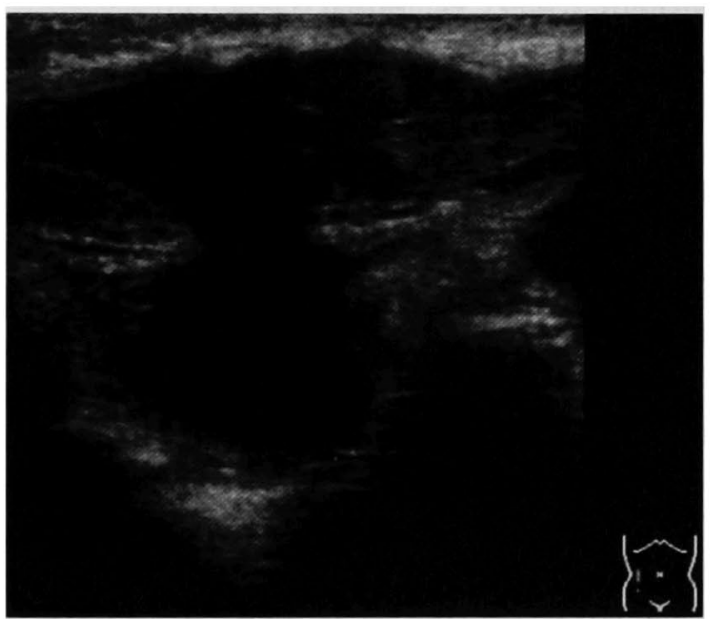

図 1 腹部エコー検查：虫垂切除術後洀痕部の皮下組 織内から腹壁筋群を貫き，腹腔内まで連続する不整形 で境界不明瞭，不均一な低エコー領域を認める。
一ゼ，手術手袋のパウダーに用いられるコーンスター チらなどが報告されている。また，手術既往のない炎症

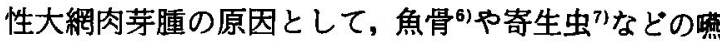
下性異物，慢性的な外傷性刺激，腹腔内臟器の炎症の 波及8などが挙げられる。

自験例では，腫瘤の核となったのは病理組織学的に みて細菌の菌塊で，成因として稀と考えられた。この 腹腔内の細菌の存在については，虫垂炎術後の遺残も しくは腹壁膿瑒の既往があるため腹腔外からの侵入が
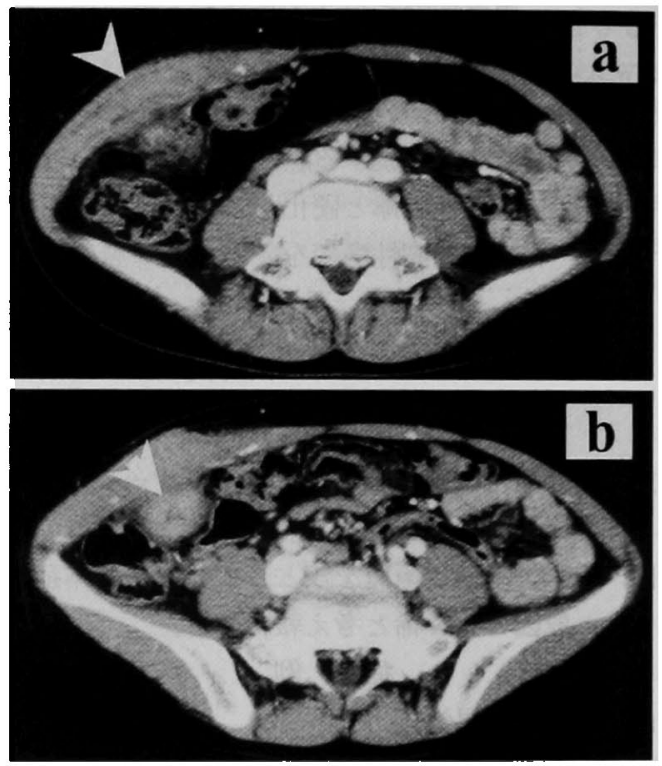

図 2 腹部造影 CT 検查：右腹壁筋群の著明な腫脹 ( $\mathbf{a}$ ：矢印), 表面平滑で辺緑に造影効果を伴う腹 腔内腫㿔（b；矢印）を認める.

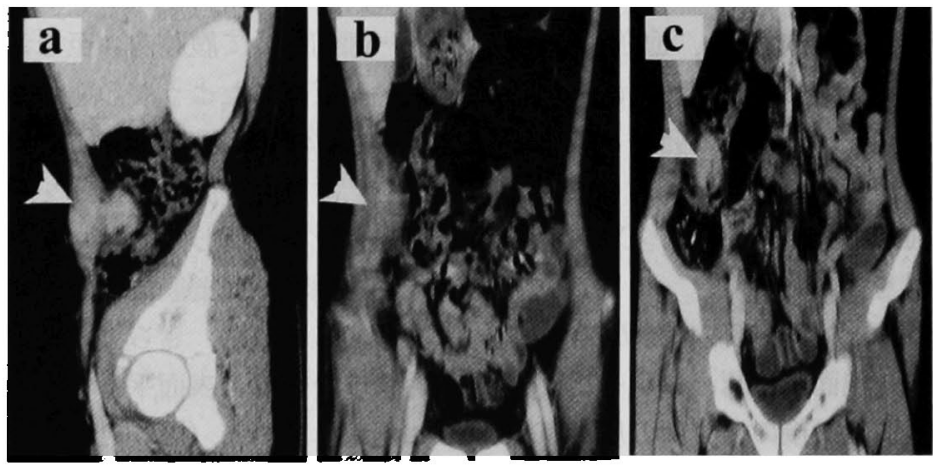

図 3 マルチスライス画像：矢状断面像で,肥厚した腹壁筋群とそれに連 続する形で腹腔内腫瘤がみられる ( $\mathbf{a}$; 矢印)。冠状断面像で, 腹壁筋群 の著明な肥厚 (b：矢印) と腹腔内腫瘦がみられ（ $\mathbf{c} ：$ 矢印），それらに よる上行結腸の圧排所見もみられる。 


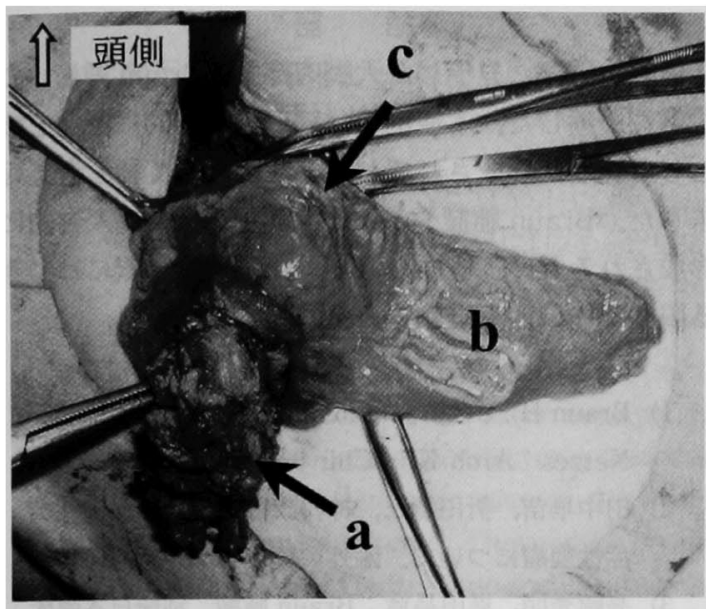

图 4 手術所見：炎症性に肥厚し，硬化した腹壁筋群 (a)，大網(b)，腹壁筋群に痣着し，大網と連続する腹 腔内腫瘤 (c).

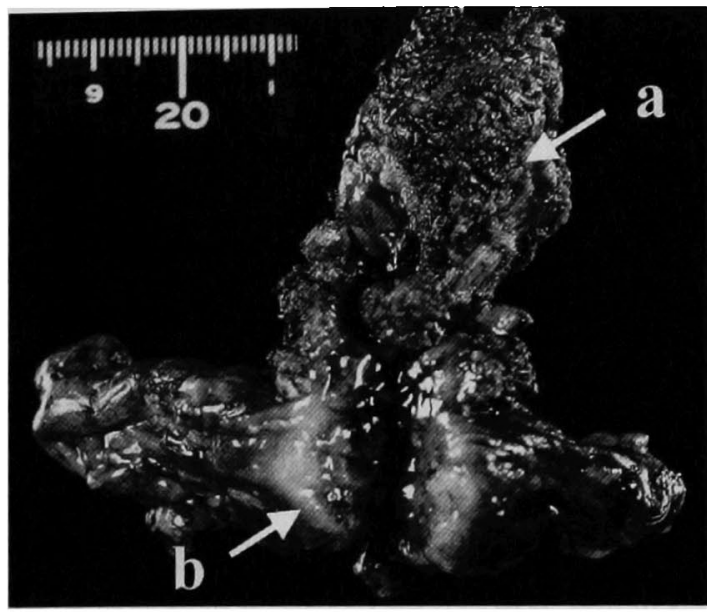

図 5 切除標本：肥厚して硬化し，腫瘤を形成した腹壁 筋群 (a), 腹壁筋群に強固に㾤着し, 大網と連続する腹 腔内腫痹 (b).

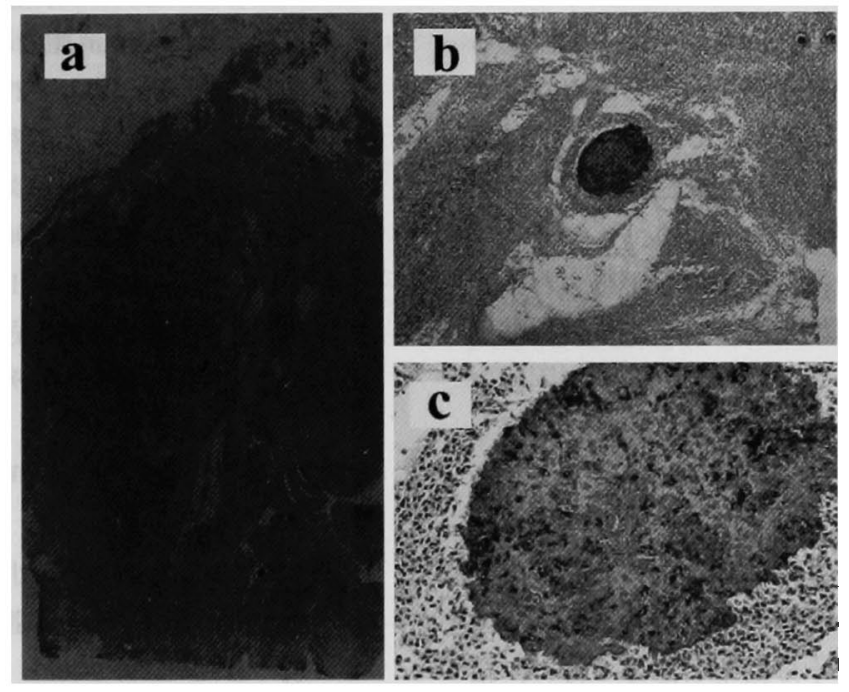

図 6 病理組織学的所見：腹壁筋群には炎症性細胞浸潤と膠原線 維の增生がみられる ( $\mathrm{a} ；$ H.E.染色 ルーぺ像)。腹腔内腫瘤は 大網の炎症性肉芽腫で, 炎症性細胞浸潤, リンパ滤胞の増生があ り，その中心に菌塊を認める（b：H.E.染色 $\times 40, \mathbf{c} ;$ H.E.染 色 $\times 200$ ).

考えられ，その判定は困難である.Braun 腫瘤が発生 するまでの期間は術後 1 週間")から数年 ${ }^{2)}$ と様々な報 告がある。自験例では 4 年と長く，その期間のほとん どは無症状で細菌感染が長期間継続したとは考えにく い. 4 年前の細菌が死滅して菌塊となり，その異物に 対する炎症反応の結果，肉芽腫が形成されたと考えら れる.
Braun 腫瘤の診断は典型的な検査所見がなく，一般 に除外診断の結果得られる。田中ら 2)はその腫瘤の特 徵として，1）硬く，境界明瞭で平滑であること，2） 圧痛，自発痛があり既往の手術との関連が考えられる こと，3）表在性であることを挙げているが，質的診 断は困難で悪性腫瘍との鑑別も難しい³．自験例では 虫垂切除術後の瘢痕部に一致して腹部腫瘤が存在して 
いた。超音波像では低エコー腫瘤で, CT 像では辺縁に 若干の造影効果を認め, 内部は造影効果の乏しい病変 として描出された。 術後膿場を思わせたが，マルチス ライス画像でも辺緑は平滑, 境界明瞭な腫瘤で典型的 な膿瘍の形態とは異なる所見であった。その結果，術 前の理学的所見や画像診断では確定診断に至らず，開 腹所見により Braun 腫瘤と診断した。疾患に対する認 識があれば，本症を念頭においての手術は可能であっ たと考えている.

創感染は消化器手術の術後合併症の一つである，早 期では術後 1 週間前後で発症する皮下峰窩織炎や膿 瘍, 晚期では腹壁に発生する異物性慢性炎症性肉芽腫 (Schloffer 腫瘤) や述べてきた炎症性大網肉芽腫 (Braun 腫瘤)などがある，自験例では腹腔内腫瘤は Braun 腫瘤と診断したが，腹壁筋群の著明に肥厚した 部分は病理組織学的に膠原絨維の增生がみられた。従

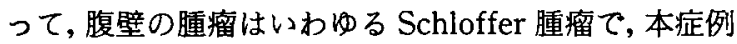
は両腫瘤の合併と考えられる，両者の関連を検証する ことは難しいが, 術後早期に創感染がみられたことか ら Schloffer 腫瘤がまず形成され，その慢性炎症の原 因菌が死滅して菌塊となり，それを成因として Braun 腫瘤が形成された可能性が考えられよう。

こうした腫瘤は良性疾患で，確定診断が得られ，無 症状であれば経過観察も可能である。しかし，自験例 のように症状がある場合，悪性腫瘍との鑑別が困難な 場合は外科的治療が選択される，予後は良好で再発も ない.

他方，人為的，医原性疾患であるという側面からそ の予防は重要である。田中ら ${ }^{2} は$ 予防法として無菌手 術を行うことのほか, 極力大網の集束結热を行わない ことを挙げ，大網の切除は十分健常な部分で行い, 結 禁系は細いものを使用すべきと述べている．さらに最 近では吸収系の使用が虛められている3 . 開腹手術の 際にはこれら諸点を考虑し，その発症を予防すること が腹部外科手術を担う者の務めと考える.
結 語

虫垂炎術後に発症した大網肉芽腫 (Braun 腫瘵)の 1 例を経験した，本症例では病理組織学的に菌塊を核 として瘇㿎が形成されており，成因として稀と考え報 告した. Braun 腫瘤や Schloffer 腫瘤などは人為的に 形成されるという側面もあり，開腹手術の際にはでき る限りその原因を排除する努力が必要である.

\section{文献}

1) Braun $H$ : Ueber. entzundliche Geschwulste des Netzes. Arch Klin Chir $63: 378-399,1901$

2）田中早苗，折田薰三，神村政行：大網の単純性炎 症性腫嘴について。臨外 $17: 1222-1228,1962$

3）高崎秀明，恩田昌彦：Braun 腫瘤。別冊日本臨床 領域別症候群シリーズ, 腹膜・後腹膜・腸間膜 ・ 大網・小網・横隔膜症候群, 11 , 日本臨牀社, 大 阪, 1996, p303-305

4）犬塚和徳，北村 宏，岩瀬正紀他：結热系が原因 と思われた Braun 尰㿔によるイレウスの 1 例. 日 臨外会誌 $65 ： 2780-2784,2004$

5）後小路世士夫, 矢部清寿, 宮本洋寿他：手術手袋 のスターチによる大網炎症性肉芽腫の1例，日臨 外会誌 $51: 2553,1990$

6）三山健司, 岩瀬和泉, 田中洋一他：腹壁浸潤を伴 い，大網の悪性腫愓を思わせた，魚骨を中心とし た巨大炎症性腫瘤の 1 例。埼玉医会誌 $21 ： 672-$ 675,1986

7）石井弘子, 峰 高義, 角田耕造他：腸アニサキス 症の 4 症例. 和歌山医 $44: 433-441,1993$

8）伊神 剛, 長谷川洋, 小木曾清二他：出血を呈し た大網肉芽腫（Braun 腫瘤）の 1 例. 日臨外会誌 $62: 2292-2297,2001$

9）長谷川剛，牧野駿一，田中 潔他：小児急性虫垂 炎術後 Braun 腫瘤の 2 症例. 日外連会18回学術抄 録：435, 1993 


\title{
A CASE OF GRANULOMA OF THE GREATER OMENTUM (A BRAUN TUMOR) FORMED WITH DRUSE AS A CORE AFTER SURGERY FOR APPENDICITIS
}

\author{
Hisaki YAMASHITA, Akira HIRANO, Hiroshi IMAMURA, \\ Tadao SHIMIZU, Yoshihiko NARITAKA and Kenji OGAWA \\ Department of Surgery, Tokyo Women's Medical University Medical Center East
}

This paper presents a case of granuloma of the greater omentum (a Braun tumor) which was formed with bacterial focus as a core after surgery for appendicitis. The patient was a 10-year-old boy. Previous history disclosed appendectomy and abscess formation in the abdominal wall as a postoperative complication. The patient was seen at the hospital because of right lower abdominal pain and fever 3 years after the appendectomy. There were prominent redness and tenderness in the right lower quadrant of abdomen. Abdominal ultrasonograpy showed a hypo-echoic area which continued from the subcutaneous structure to abdominal cavity. Abdominal CT scan revealed inflammatory findings of the abdominal wall muscle and an abdominal tumor with enhancement which continued from the inflammation. An intraabdominal tumor or abscess continued from the abdominal wall was diagnosed. Upon laparotomy, we saw remarkable inflammatory thickening and induration of the abdominal wall muscle, and, in the abdominal cavity, a tumorous lesion with conglomerated greater omentum which was firmly adhesive with the induration. The tumorous lesion was diagnosed as omental granuloma (Braun tumor) involving bacterial focus as a core. 